\title{
The Behavior of Strength Properties from Three Different Tree Boles of Aras in Sarawak
}

\author{
Gaddafi Ismaili, Badorul Hisham Abu Bakar and Khairul Khuzaimah Abdul Rahim
}

\begin{abstract}
Aras had been selected and tested in small clear specimens. Sampling of test specimens are made from three sections of the tree bole namely from bottom, middle, and top parts. This paper looks into the information of strength properties from three sections of sampled. The strength properties test required are the modulus of rupture, modulus of elasticity and compression stress parallel to grain. Meanwhile, the physical properties' test referred to moisture content and basic density. The testing conducted in two different conditions of the trees, which were referred to green and air-dry condition. It was found that the average mean values for modulus of rupture, modulus of elasticity and compressive stress parallel to grain tested at green condition were $47.52 \mathrm{~N} / \mathrm{mm}^{2}, 6358.56 \mathrm{~N} / \mathrm{mm}^{2}$ and $22.42 \mathrm{~N} / \mathrm{mm}^{2}$ respectively meanwhile at airdry condition were $70.49 \mathrm{~N} / \mathrm{mm}^{2}, 8217.64 \mathrm{~N} / \mathrm{mm}^{2}$ and $34.07 \mathrm{~N} / \mathrm{mm}^{2}$ respectively. Meanwhile, the average mean values for moisture content at green condition were $83.34 \%$ whilst at the air-dry condition were $12.33 \%$. Basic density remains unchanged from both conditions.
\end{abstract}

Keywords: Modulus of rupture, modulus of elasticity, compression stress parallel to grain, moisture content, basic density

\section{INTRODUCTION}

$\mathrm{G}$ enerally, log production in Malaysia is mainly to accommodate the huge demand for general utility timber for industrial purposes. Nowadays, timber industries in Malaysia have involved into cores of plywood and make up the major constituent of fibreboard, particleboard, interior construction wood, and other low grade use. [1]. Sarawak consists of numerous indigenous species of fast growing timber. From these species, there are several which has been identified to be potential species for light wood industries utilisation and for engineering structural design purposes as alternative species. The potential species are referred to Engkabang jantong, Aras, Terbulan, Kelampayan, Sawih, Benuang and, etc. Each of these species has its own characteristics and behaviour whether in terms of physical or strength properties. Therefore, there is a need to get some basic information on its strength and physical properties. Small clear specimens or defect free samples were used to know the strength properties and physical properties distribution within the tree bole viz., from bottom, middle and top parts. For this paper, Aras has been selected for this study.

Aras is a type of tree known by the locals in Sarawak. It is known by its botanical name as Ilex cissoidea. In Sabah, this species is known as bangkulatan and morogis, while in Peninsular Malaysia, this species is known as timah-timah. Meanwhile, in Indonesia it is known as Mensira gunung. Ilex cissoidea is categorized in Aquifoliaceae family that is commonly found throughout the temperate and tropical regions of the world, mainly in South East Asia. Its sapwood is not differentiated from the heartwood, which is white and darkens on exposure to be yellow-brown. The timber is of medium density Light Hardwood, ranging from $560-595 \mathrm{~kg} / \mathrm{m}^{3}$ in air-dry condition. The timber is non-durable and is subject to attacks by sapstain fungi. The grain is straight, and the texture is fine but uneven due to the presence of the broad rays. The split surface has a considerable sheen. This timber is reported to season well with only slight splitting [2]. This genus is rather rare in an occurrence and coupled with its small size. The timber is very unlikely to be of any commercial importance. However, this timber has been tried successfully for match splints and may be a good furniture timber if available in large enough quantities.[2]

Gaddafi Ismaili was with Reliability Integrity Engineering Department, PETRONAS Carigali Sdn. Bhd., Sarawak Operations, Jalan Sekolah, 98008, Lutong, Miri, Sarawak. He is now with the Faculty of Engineering, Universiti Malaysia Sarawak, Kota Samarahan, 94300 Kota Samarahan, Sarawak, Malaysia (phone: +60 8258 3432; fax: +60 82 583409; e-mail: igaddafi@feng.unimas.my).

Assoc. Prof Dr. Badorul Hisham Abu Bakar is with the School of Civil Engineering, Universiti Sains Malaysia, Engineering Campus, 14300, Nibong Tebal, Seberang Perai, Pulau Pinang, Malaysia (phone: +604 5996298; fax: +604 5941009; e-mail: cebad@eng.usm.my).

Khairul Khuzaimah Abdul Rahim, was with Applied Forest Science and Industry Development Division, Sarawak Forestry Corporation Sdn. Bhd., Lot 218, KCLD Jalan Tapang, Kota Sentosa, 93250 Kuching, Sarawak Malaysia. She is now with the Infrastructure Planning and Development, Protected Areas and Biodiversity Conservation Divison, Sarawak Forestry Corporation Sdn Bhd, Lot 218, KCLD Jalan Tapang, Kota Sentosa, 93250 Kuching, Sarawak Malaysia (phone: +60 8262 9667; fax: +60 8262 9450; e-mail: khairulkr@ sarawakforestry.com) 


\section{Materials AND Testing Methods}

Materials and sampling methods

A total of 335 selected specimens of Aras were used in this study. The collection of the species was done at Sabal Reforestation Plot. The selected species were then be made into three sections of tree bole namely bottom, middle and top. At the site, the $\log$ of about $1.53 \mathrm{~m}$ in length was then ripped through the pith to obtain two flitches and transported to the processing factory where the flitches be machined into boards. The boards were subsequently machined to produce exactly $20 \mathrm{~mm}$ square sticks. The sticks were visually graded, and only defect free green as well as air-dry samples were cut into specified length and brought to mechanical testing facility to be tested.

\section{Strength properties}

All the strength properties were conducted in accordance to the British Standard BS 373: 1957 [3]. The results were obtained from the testing conducted by using destructive test (DT) in two different timber conditions, i.e. green and air-dry conditions. The strength properties that were tested were the modulus of rupture, modulus of elasticity and compression stress parallel to grain. An Instron Universal Testing Machines with loading capacity of $50 \mathrm{kN}$ was used to determine the strength values of the wood specimens. The loading rate for static bending and compression parallel to grain was $6.6 \mathrm{~mm}$ per minimum and $0.6 \mathrm{~mm}$ per minimum respectively. The testing room was maintained at temperature of $20 \pm 3^{\circ} \mathrm{C}$.

\section{Physical properties}

\section{Moisture content determination}

Moisture content (MC) determination was conducted directly after the wood processing was completed. At that point, the initial weights were taken. Then, samples were placed in the oven at $103 \pm 2{ }^{\circ} \mathrm{C}$ until the constant weight was achieved. The percentage of moisture content was calculated on the dry weight basis. The formula for calculating moisture content is shown below.

$$
\operatorname{MC}(\%)=\frac{\text { Initial weight }- \text { Oven dried weight }}{\text { Oven dried weight }} \times 100
$$

\section{Basic density determination}

The specimens were calculated from the ratio of oven-dried weight to green volume. Water displacement method was used to get the green volume, and the dry weight was measured using an electronic balance. The formula for calculating the basic density is as shown below.

Basic density $\left(\mathrm{g} / \mathrm{cm}^{3}\right)=\frac{\text { Oven dried weight }}{\text { Green volume }}$

\section{RESULTS AND DISCUSSION}

\section{Main Test Results of Small Clear Specimens}

The test results for modulus of rupture, modulus of elasticity, compressive stress parallel to grain, basic density and moisture content of small clear specimens of Aras are shown in Table 1. Total number of 67 specimens from green and airdry condition was tested for each test. The basic density was $0.37 \mathrm{~g} / \mathrm{cm}^{3}$ and classified under Light Hardwood based on Malaysian Grading Rules [4]. In terms of compressive strength with reference to Malaysian Grading Rule, it is classified under the strength group SG7 [4]. The average mean values for modulus of rupture, modulus of elasticity and compressive stress parallel to grain tested at green condition were $59.01 \mathrm{~N} / \mathrm{mm}^{2}, 7288.10 \mathrm{~N} / \mathrm{mm}^{2}$ and $28.25 \mathrm{~N} / \mathrm{mm}^{2}$ respectively. This timber can be use for joinery, matches, pattern making, boxes and crates, furniture components, plywood, light construction, carvings and wooden shoes. [5]. 
Table 1: Test results of small clear specimens of Aras.

\begin{tabular}{|c|c|c|c|c|c|}
\hline $\begin{array}{l}\text { Statistical } \\
\text { Analyses }\end{array}$ & $\begin{array}{l}\text { Modulus of } \\
\text { rupture } \\
\left(\mathrm{N} / \mathrm{mm}^{2}\right)\end{array}$ & $\begin{array}{l}\text { Modulus of } \\
\text { elasticity } \\
\left(\mathrm{N} / \mathrm{mm}^{2}\right)\end{array}$ & $\begin{array}{l}\text { Compression } \\
\text { stress parallel } \\
\text { to grain } \\
\left(\mathrm{N} / \mathrm{mm}^{2}\right)\end{array}$ & $\begin{array}{l}\text { Density } \\
\left(\mathrm{g} / \mathrm{cm}^{3}\right)\end{array}$ & $\begin{array}{c}\text { Moisture content } \\
\text { (\%) }\end{array}$ \\
\hline Mean & 57.40 & 7162.36 & 27.49 & 0.37 & 52.59 \\
\hline STDEV & 15.75 & 1509.47 & 7.50 & 0.04 & 36.13 \\
\hline $\mathrm{CV}(\%)$ & 27.43 & 21.08 & 27.27 & 10.79 & 68.70 \\
\hline $\mathrm{N}$ & 67.0 & 67.0 & 67.0 & 67.0 & 67.0 \\
\hline & $\begin{array}{l}\text { Note: } \\
\text { Mean } \\
\text { STDEV } \\
\text { CV } \\
\text { N }\end{array}$ & \multicolumn{4}{|c|}{$\begin{array}{l}=\text { Mean values } \\
=\text { Standard deviation } \\
=\text { Coefficient of variation } \\
=\text { Number of specimens }\end{array}$} \\
\hline
\end{tabular}

Distribution Pattern of Strength Properties within the tree bole

The results for strength properties test for modulus of rupture, modulus of elasticity and compressive stress parallel to grain were represented in Figure 1, Figure 2 and Figure 3 respectively. From the observation, specimens at green condition showed the highest modulus of rupture mean values possessed by top tree bole with $49.29 \mathrm{~N} / \mathrm{mm}^{2}$ followed by bottom and middle tree bole with the mean value of $46.79 \mathrm{~N} / \mathrm{mm}^{2}$ and $46.48 \mathrm{~N} / \mathrm{mm}^{2}$ respectively. For modulus of elasticity, the top tree bole remained with the highest mean value of $6604.07 \mathrm{~N} / \mathrm{mm}^{2}$ followed by bottom and middle tree bole with mean values of $6301.71 \mathrm{~N} / \mathrm{mm}^{2}$ and $6169.89 \mathrm{~N} / \mathrm{mm}^{2}$ respectively. Meanwhile, the mean value for compression stress parallel to grain revealed that bottom and top tree bole recorded with the same mean value of $22.70 \mathrm{~N} / \mathrm{mm}^{2}$ whilst the middle tree top with $3.5 \%$ different with mean value of $21.87 \mathrm{~N} / \mathrm{mm}^{2}$.

Meanwhile, at the air-dry condition, the middle tree bole section recorded the highest modulus of rupture mean value with $73.76 \mathrm{~N} / \mathrm{mm}^{2}$ followed by the bottom and top tree bole with mean values of $69.68 \mathrm{~N} / \mathrm{mm}^{2}$ and $68.04 \mathrm{~N} / \mathrm{mm}^{2}$ respectively. The middle tree bole section also registered the highest mean value for modulus of elasticity and subsequently followed by top and bottom tree bole section with the mean values of $8618.11 \mathrm{~N} / \mathrm{mm}^{2}, 8159.91 \mathrm{~N} / \mathrm{mm}^{2}$ and $7874.89 \mathrm{~N} / \mathrm{mm}^{2}$ respectively. Moreover, for compression stress parallel to grain, middle tree bole section with the mean value of $36.12 \mathrm{~N} / \mathrm{mm}^{2}$ also gave the highest mean value followed by bottom and top tree section with mean values of $30.91 \mathrm{~N} / \mathrm{mm}^{2}$ and $35.20 \mathrm{~N} / \mathrm{mm}^{2}$ respectively.

The differences between the three tree bole sections at the green and air-dry condition are represented in its percentages different. For modulus of rupture, the middle tree bole section at the air-dry is $37 \%$ higher compared to at green condition, which was the highest followed by bottom and top section with $32.8 \%$ and $27.6 \%$ respectively. The same case was observed for modulus of elasticity, where the middle section has the highest difference followed by bottom and top with the condition showed the difference of $28.4 \%, 20.0 \%$ and $19.1 \%$ higher compared to than at green condition respectively. The compression stress parallel to grain also showed that middle tree bole section has the highest difference with air-dry giving higher values than green condition at $39.5 \%$ followed by top and bottom section at $35.5 \%$ and $26.6 \%$ respectively. From the finding, the strength properties values for Aras at green condition was found to be higher at the top tree bole section and with a $3.2 \%$ difference compared to the strength properties values at the bottom tree bole section. At the air-dry condition, the higher strength properties values possessed by the middle tree bole section with $5.2 \%$ different as compared to the strength properties values at the bottom tree bole section. It was found that, the outcome from this finding was contrary with [6], where timbers from butt logs are expected to be slightly stronger than top logs. However, the basic density results for both green and air-dry condition was agreed with [6], where timbers at the bottom tree bole section are slightly denser than the top tree bole section. Timber is physically specified as heterogeneous characteristic. This characteristic prompt to fluctuate in its strength properties even though within the same species. The difference in the strength properties between species is further accentuated if injurious defects such as knots, sloping grain are present, as some species are more prone to contain such defects [7].
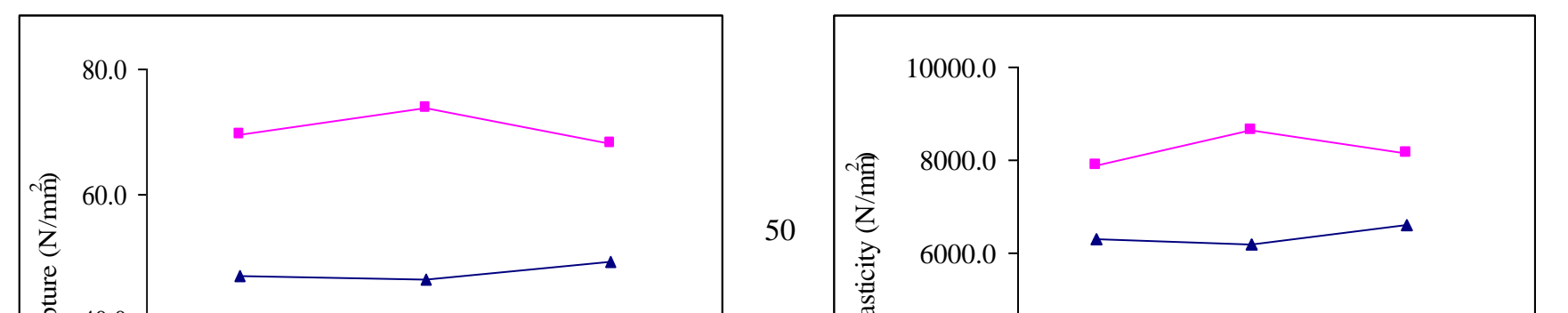
Figure 1 Modulus of rupture versus tree bole sections.

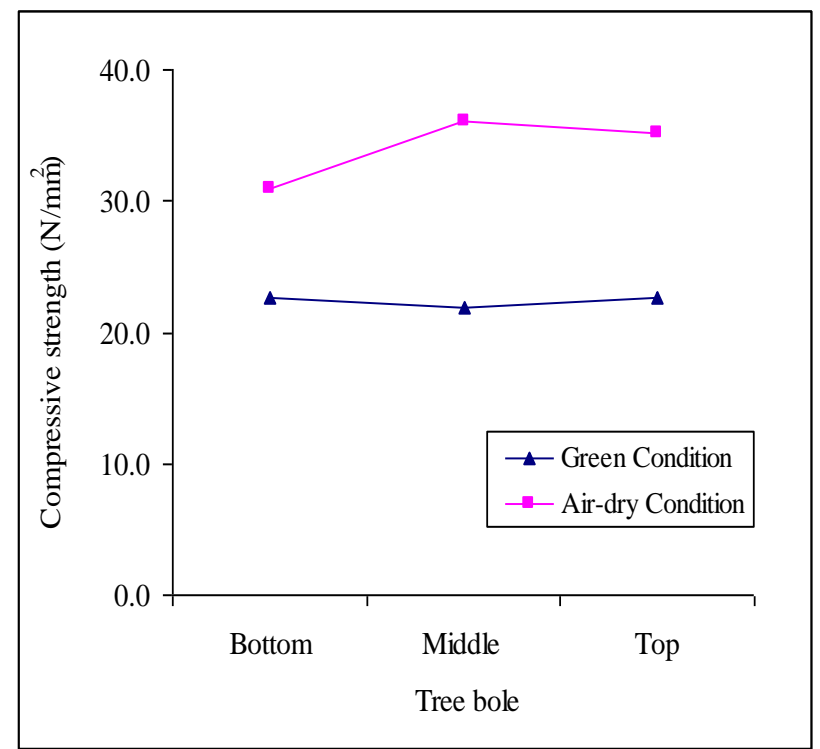

Figure 3 Compressive strength versus tree bole sections.

Distribution Pattern of Physical Properties within the tree bole

For the physical properties, the highest mean value of moisture content at green condition possessed by middle tree bole with the mean value of $86.95 \%$ followed by bottom and top tree bole with mean value of 84.08 and $78.98 \%$ respectively. At top tree bole section had the highest basic density with the value of $0.38 \mathrm{~g} / \mathrm{cm}^{3}$, meanwhile at the bottom and middle tree bole gave the same mean value of $0.36 \mathrm{~g} / \mathrm{cm}^{3}$.

At air-dry condition, the bottom tree bole section had the highest moisture content compared to top and middle tree bole section with value of $12.69 \%, 12.22 \%$ and $12.09 \%$ correspondingly. The highest basic density possessed by the top tree bole section with $0.38 \mathrm{~g} / \mathrm{cm}^{3}$ followed by middle and top tree bole with the value of $0.37 \mathrm{~g} / \mathrm{cm}^{3}$ and $0.36 \mathrm{~g} / \mathrm{cm}^{3}$ respectively. However, it was obvious that the difference of moisture content was higher at green compare to air-dry condition by middle section with the highest difference followed by bottom and top section by $86.1 \%, 84.9 \%$ and $84.5 \%$ respectively. The results at air-dry condition were in agreement with [4], where wood increases in strength as it dries. The results for moisture content and basic density test are presented in Figure 4 and Figure 5 respectively.
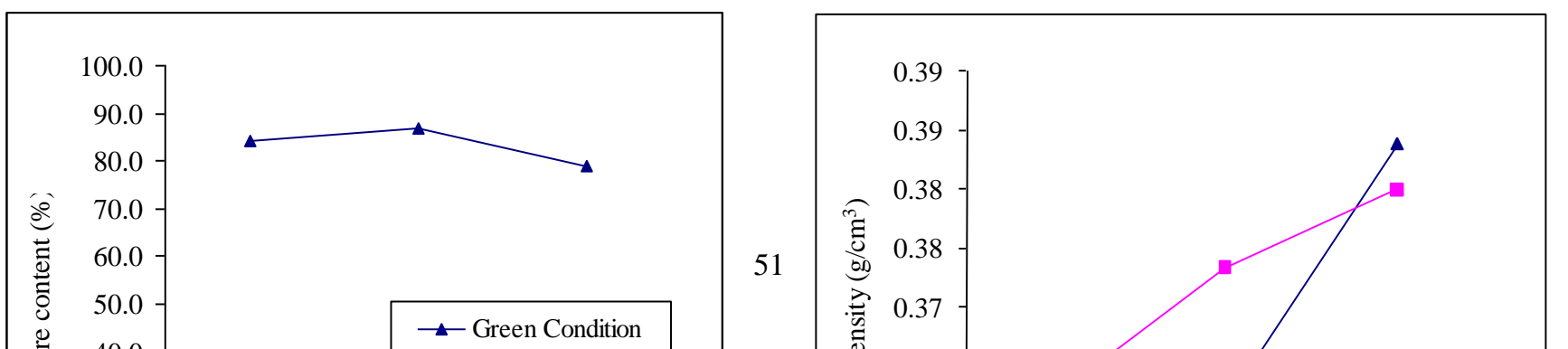
UNIMAS E-Journal of Civil Engineering, Vol. 2 (2) 2011

\section{CONCLUSION}

Aras is classified under Light Hardwood and in terms of its strength, it is categorized under the strength group SG7. The species was recommended mainly for general utility for furniture making and other non-structural applications. It was found that the strength properties values for modulus of rupture, modulus of elasticity and compressive stress parallel to grain at green condition showed that highest values possessed by top tree bole section. Whilst at the air-dry condition, the highest value was possessed by middle tree bole section. The basic density also showed a similar trend which was reported higher at top tree bole section for both green and air-dry condition.

\section{ACKNOWLEDGMENT}

The authors would like to gratefully acknowledge everyone involve in this project, especially to Research Manager, Dr. Alik Duju. Thank you all for your guidance and support.

\section{REFERENCES}

[1] Krishnapillay B. and Abdul Razak Mohd Ali (1998). Feasibility of Planning High Quality Timber Species in Peninsular Malaysia. In Proceeding of the Seminar on High Value Timber Species for Plantation Establishment-Teak and Mahoganies, 1-2 December 1998, Tawau, Sabah. 91-101pp

[2] Anon. (2006). MTC Wood Wizard. Malaysian Timber Council. [WWW ${ }^{5}$ ] htttp://woodwizard.my/asearch.asp > [Accessed 28 September 2008]

[3] British Standard (1957). Methods of Testing Small Clear Specimen of Timber. British Standard Institution. BS 373: 1957. 31pp.

[4] Anon. (2011). Malaysian Grading Rules, Malaysian Timber Industry Board, (MTIB), (2011). $\left[\mathrm{WWW}^{13}\right]<$ http://www.mtib.gov.my/index.php?option=com content\&view=article\&id=78:malaysia-grading-rules\&catid=40:service $>[$ Accessed 2 August 2008]

[5] Richter, H.G. \& Dallwitz, M.J., 2000. Commercial timber: descriptions, illustrations, identification, and information retrieval. [WWW $\left.{ }^{16}\right]<$ http://deltaintkey.com/wood/index.htm>[Accessed 12 Jun 2008]

[6] Keith R. Bootle (1985), Wood in Australia: Type, properties and uses. McGraw-Hill Book Co. Australia. 29, 60-61pp.

[7] R.G. Pearson, N.H. Kloot and J.D. Boyd (1962). Timber Engineering Design Handbook, Jacaranda Press Pty Ltd. Australia, 19, 22-23pp. 